\title{
Evaluation of process parameters in the industrial scale production of fish nuggets
}

\author{
Avaliação de parâmetros de processo na produção de empanados de peixe em escala industrial
}

\author{
Adriane da SILVA ${ }^{1}$, João ZITKOSKI ${ }^{1}$, Marcio Antônio MAZUTTI², Altemir MOSSI ${ }^{1}$, José Vladimir OLIVEIRA ${ }^{1}$, \\ Débora de OLIVEIRA ${ }^{1}$, Alexandre José CICHOSKI ${ }^{1}$, Helen TREICHEL ${ }^{1 *}$
}

\begin{abstract}
This work reports the use of experimental design for the assessment of the effects of process parameters on the production of fish nuggets in an industrial scale environment. The effect of independent factors on the physicochemical and microbiological parameters was investigated through a full 24 experimental design. The studied factors included the temperature of fish fillet and pulp in the mixer, the temperature of the added fat, the temperature of water and the ratio of protein extraction time to emulsion time. The physicochemical analyses showed that the higher temperature of the pulp and fillet of fish, the lower the protein in the final product. Microbiological analyses revealed that the counting of Staphylococcus coagulase positive, total and thermo-tolerant coliforms were in accordance with the current legislation.

Keywords: fish nuggets; experimental design; process parameters.
\end{abstract}

\section{Resumo}

Este trabalho teve como objetivo o uso da metodologia de planejamento de experimentos para avaliação dos efeitos de parâmetros de processo na produção de empanados de peixe em escala industrial. Os efeitos destes parâmetros nas características físico-químicas e microbiológicas do produto final foram avaliados através de um planejamento completo 24 . As variáveis independentes estudadas foram temperaturas do filé e da polpa, temperatura da gordura e da água adicionadas na formulação do produto, bem como razão entre tempo de extração da proteína e tempo de emulsão. As análises físico-químicas mostraram que maiores temperaturas de adição de polpa e filé de peixe resultaram em uma menor concentração de proteína no produto final. As análises microbiológicas realizadas resultaram em contagens de Staphylococcus coagulase positiva, totais e termotolerantes de acordo com a legislação vigente.

Palavras-chave: empanados de peixe; planejamento de experimentos; parâmetros de processo.

\section{Introduction}

Fish meat has excellent nutritional value, being rich in proteins, vitamins and unsaturated (w-3) fatty acids (GERMANO; OLIVEIRA; GERMANO, 1993; FRANCO; LANDGRAF, 1996). Fish and mechanically separated meat (MSM) are important sources of proteins; minerals, mainly calcium and phosphorus; and vitamins A, D and B, which make them products of high nutritional value (HALL, 1992; SU et al., 2003; CASTRO et al., 2004).

Tilapia (Oreochromis niloticus) is the second fish species in terms of production in the whole world (JORY; ALCESTE; CABRERA, 2000). The main exporters of tilapia are South American countries, such as Costa Rica, Ecuador and Honduras (JORY; ALCESTE; CABRERA, 2000; REDMAYNE, 2000).

Considering the tendency of increasing demand for food products, mainly those having proteins of high nutritional values, the use of fish proteins, especially from species of low commercial value or from by-products, seems to be a promising and interesting alternative for both consumers and food market.

In this context, the main objective of this work was to evaluate some process parameters, in the industrial scale environment, for the production of a fish industrialized derivative. For this purpose, it was adopted an experimental design towards assessing physicochemical and microbiological characteristics of the final product.

\section{Materials and methods}

Fillets of tilapia (Oreochromis niloticus) and carp (Cyprinus carpio), and mechanically separated meat (MSM) of both fish species were kindly donated by 'Cardume Indústria e Comércio de Peixes Ltda' (Chapecó, SC, Brazil). The ingredients used for product formulation were the following: soy hydrogenated lipid (COAMO), soy texturized protein (DUPLOGEL MF MARSUL), soy concentrated protein (PROTIMARTI GV AP MARSUL), carrageen (GENU IBRACK), salt and spices (COMPACTO 2172; IBRACK), water, whole milk and thickener for nuggets (C-B 420; BREMIL).

\subsection{Nuggets production}

The fillets and MSM samples were stored at $-14^{\circ} \mathrm{C}\left( \pm 1{ }^{\circ} \mathrm{C}\right)$. Before nuggets production, the raw materials were removed

Received 27/5/2009

Accepted 13/11/2009 (004226)

${ }^{1}$ Department of Food Engineering, URI - Campus Erechim, Av. Sete de Setembro, 1621, CP 743, CEP 99700-000, Erechim - RS, Brazil

${ }^{2}$ Departamento de Engenharia Química, Universidade Federal de Santa Maria - UFSM, Av. Roraima, 1000, CEP 97105-900, Santa Maria - RS, Brasil, E-mail: helen@uricer.edu.br

${ }^{*}$ Corresponding author 
from the freezing chambers and kept at $6{ }^{\circ} \mathrm{C}$ until reaching the temperatures established for the experimental design. The fillets, MSM, additives and other ingredients were weighed taking into account the product formulation previously established by the industry.

The raw materials were ground in industrial mill $(3 \mathrm{~mm}$ diameter) twice. Before grinding, the soy texturized protein (flakes) was hydrated for 12 hours in filtered water at $8.5^{\circ} \mathrm{C}$ (mass ratio of 1.3:4). The raw materials were mixed following a pre-established order defined for nuggets production, as shown in Table 1. All nugget samples were collected after mixing the raw materials.

The effect of some process variables were evaluated through a full $2^{4}$ experimental design with triplicate measurements at the central point, thus resulting in a total of 19 experiments. All experiments were performed in the industrial unit. The independent variables evaluated were temperature of fillet and MSM $\left(-6^{\circ} \mathrm{C}\right.$ to $\left.-2{ }^{\circ} \mathrm{C}\right)$; temperature of fat $\left(10^{\circ} \mathrm{C}\right.$ to $\left.14{ }^{\circ} \mathrm{C}\right)$; water temperature $\left(6^{\circ} \mathrm{C}\right.$ to $\left.10^{\circ} \mathrm{C}\right)$; and ratio of extraction time/emulsion time (4/12 to 8/14). After processing, all nugget samples were evaluated in terms of physicochemical and microbiological analyses.

\subsection{Analytical methods}

Protein, lipids, ash and $p H$ determinations

The protein content was determined by Kjeldhal method (VELP Scientifica, model VDK126A). The lipid concentration was determined by organic solvent extraction (Soxhlet). The ash content was evaluated using an oven at $550{ }^{\circ} \mathrm{C}$ (Brasimet, model $\left.\mathrm{K}, 1,300{ }^{\circ} \mathrm{C}\right)$. The $\mathrm{pH}$ values were determined using a $\mathrm{pH}$-meter (Analyser, model pH300). All the methodologies employed followed the standards established by the Brazilian Health Minister (BRASIL, 2005).

Water activity $\left(\mathrm{a}_{\mathrm{w}}\right)$ determination

The $a_{\mathrm{w}}$ values were determined using the Aqualab CX-2 Water Activity-System, calibrated with deionized water and $\mathrm{NaCl}$ solution (18.5\%).

Table 1. Sequence of ingredients addition in the fish nuggets production.

\begin{tabular}{lc}
\hline \multicolumn{1}{c}{ Ingredients } & Mixing time (minutes) \\
\hline Fillet and MSM & 1 \\
Salt & 1 \\
Water & 1 \\
Additives & 1 \\
1/3 of total fat & 2 \\
Soy protein (flakes) & 3 \\
Soy protein (powder) & 2 \\
2/3 of total fat & 3 \\
Powdered milk & 2 \\
\hline
\end{tabular}

\section{Moisture content}

The moisture content was determined by the method of desiccation in oven with air circulation (model FANEM 320-SE) at $105^{\circ} \mathrm{C}$, as described by IAL (INSTITUTO..., 1985).

\section{Color evaluation}

The CIE coordinates $L^{*}$ (lightness), $a^{*}$ (red-green), and $b^{*}$ (yellow-blue) of fish nuggets were determined using a Colorimeter Minolta CR400 (Konica Minolta). Three readings were performed for each replicate to obtain uniform color measurements.

\subsection{Microbiological methods}

About $25 \mathrm{~g}$ of the product were transferred to a sterile stomacher bag and $225 \mathrm{~mL}$ of sterile $0.1 \%$ peptone water (Oxoid) were added and mixed for 1 minute in a Stomacher machine (ITR mod. MK 1204). Serial decimal dilutions in $0.1 \%$ peptone water were prepared and $1 \mathrm{~mL}$ or $0.1 \mathrm{~mL}$ samples of appropriate dilutions were poured or spread in duplicate. Analyses were carried out according to APHA (AMERICAN..., 1992): (a) Staphylococcus coagulase positive on Baird-Parker medium (Oxoid) with egg yolk tellurite emulsion (Oxoid) incubated at $37^{\circ} \mathrm{C}$ for $24-48$ hours; (b) total coliforms on Brilliant Green Bile (2\%) Broth (Oxoid) after 48 hours at $37^{\circ} \mathrm{C}$ (MPN method); and (c) thermo-tolerant coliforms on EC broth (Oxoid) incubated at $42{ }^{\circ} \mathrm{C}$ for 24 hours (MPN method).

\subsection{Statistical analysis}

The experimental data were analyzed through the experimental design methodology and analysis of variance followed by Tukey's test ( $p<0.05$ ), using the software Statistica 5.0 (MONTGOMERY, 1991).

\section{Results and discussion}

\subsection{Physicochemical analyses}

Table 2 presents the results obtained from the physicochemical analyses. As it can be seen in this table, fat content values varied from 4.0 to $14.0 \%$ for experiments 1 and 4 , respectively. The lower value (experiment 1) corresponds to the lowest ratio of protein extraction time to emulsion time and also to the lowest water temperature $\left(6^{\circ} \mathrm{C}\right)$. These two factors hampered the extraction of myofibrillars proteins, leading to poor emulsion formation. The highest fat content $(14.0 \%)$ may be associated with the higher levels of temperature of the raw material (fillet, MSM) and fat. The high viscosity of fat can favor the formation of lower particles that require longer times to be reduced to very small particles.

Figure 1 presents the Pareto chart showing the effect of the studied variables on the fat content of the produced fish nuggets. One can observe that the water temperature and the ratio of protein extraction time to emulsion time had a significant effect on the fat content of fish nuggets. The effect of these variables 
Table 2. Physicochemical analyses in the fish nuggets product in terms of experimental conditions established in the experimental design.

\begin{tabular}{|c|c|c|c|c|c|c|c|c|c|}
\hline Run & Fat (\%) & Protein (\%) & Ash (\%) & $\mathrm{pH}$ & $a_{w}$ & Moisture (\%) & $\mathrm{L}^{*}$ & $a^{*}$ & $b^{*}$ \\
\hline 1 & 6.1 & 18.7 & 2.2 & 6.1 & 0.99 & 71.3 & 69.7 & 7.5 & 15.8 \\
\hline 2 & 7.1 & 16.0 & 3.2 & 6.5 & 0.99 & 67.1 & 69.0 & 7.1 & 16.3 \\
\hline 3 & 6.9 & 18.3 & 3.0 & 6.1 & 0.99 & 64.3 & 63.6 & 8.4 & 17.9 \\
\hline 4 & 4.0 & 17.3 & 3.2 & 6.4 & 0.98 & 63.9 & 68.5 & 8.4 & 15.4 \\
\hline 5 & 9.8 & 17.2 & 1.9 & 6.9 & 0.99 & 65.6 & 62.6 & 8.3 & 13.0 \\
\hline 6 & 10.1 & 14.7 & 3.1 & 6.9 & 0.99 & 65.6 & 64.8 & 5.8 & 12.9 \\
\hline 7 & 10.2 & 15.8 & 2.1 & 6.6 & 1.00 & 66.5 & 61.0 & 7.0 & 13.3 \\
\hline 8 & 8.9 & 15.4 & 3.7 & 6.8 & 0.99 & 63.2 & 63.9 & 6.8 & 13.0 \\
\hline 9 & 13.1 & 16.0 & 3.1 & 6.4 & 0.99 & 65.1 & 67.5 & 8.9 & 17.3 \\
\hline 10 & 7.9 & 15.3 & 3.2 & 6.4 & 0.99 & 63.8 & 68.2 & 8.1 & 16.8 \\
\hline 11 & 8.1 & 17.5 & 2.6 & 6.6 & 0.99 & 65.9 & 59.9 & 6.1 & 12.9 \\
\hline 12 & 9.5 & 16.6 & 2.3 & 6.8 & 0.99 & 66.3 & 62.3 & 6.1 & 11.8 \\
\hline 13 & 12.3 & 18.1 & 2.6 & 6.6 & 1.00 & 65.5 & 62.9 & 5.8 & 13.1 \\
\hline 14 & 9.2 & 16.9 & 2.1 & 6.3 & 0.99 & 66.1 & 52.6 & 7.4 & 13.0 \\
\hline 15 & 12.0 & 17.0 & 3.0 & 6.3 & 0.99 & 65.3 & 68.5 & 7.5 & 16.5 \\
\hline 16 & 12.7 & 17.7 & 3.1 & 6.3 & 0.99 & 66.3 & 67.7 & 7.1 & 17.7 \\
\hline 17 & 6.4 & 17.4 & 2.9 & 6.2 & 0.98 & 70.7 & 70.0 & 5.0 & 17.5 \\
\hline 18 & 5.4 & 17.1 & 2.6 & 6.2 & 0.98 & 67.9 & 68.2 & 5.6 & 17.9 \\
\hline 19 & 9.5 & 17.5 & 1.9 & 6.4 & 0.99 & 66.9 & 51.8 & 8.7 & 12.4 \\
\hline
\end{tabular}

$L^{*}:$ lightness; $\mathrm{a}^{*}$ : red color; $\mathrm{b}^{*}$ : yellow color.

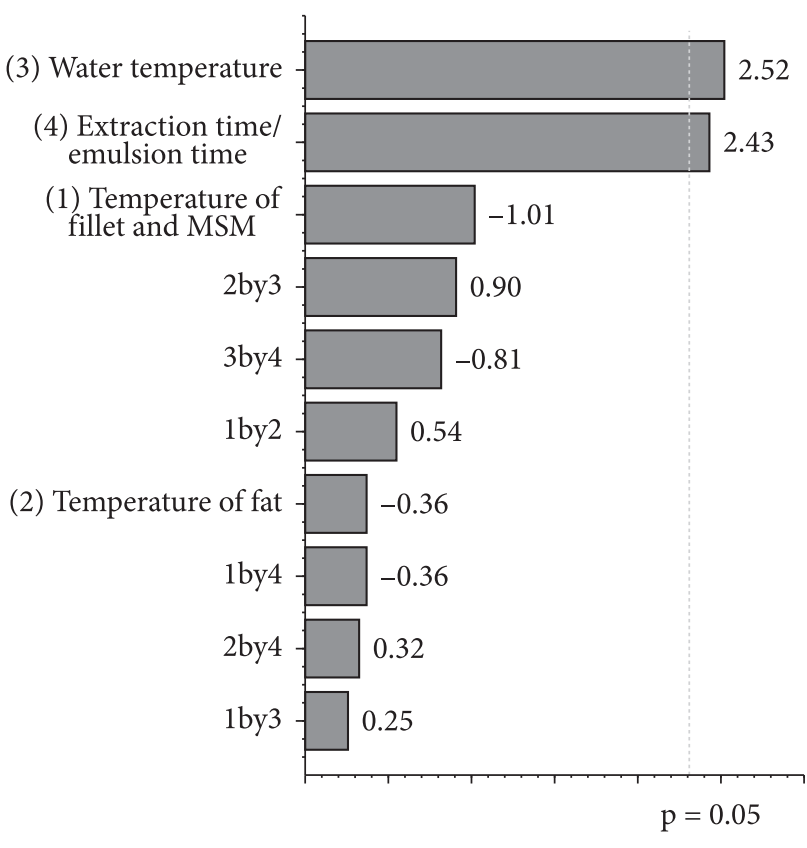

Effect estimate (absolute value)

Figure 1. Pareto chart with the estimated effect (absolute value) of variables evaluated in the full $2^{4}$ experimental design in terms of fat content.

was positive $(\mathrm{p}<0.05)$, indicating that an increase in these variables lead to higher fat content.

Peixoto, Sousa and Mota (2002) evaluated the influence of fat content on fish sausages and fish nuggets and showed that values of $1.7 \%$ and from $6.1 \%$ to $14.0 \%$ were observed for sausages and nuggets, respectively. Flores et al. (2002) reported a fat content of $6.1 \%$ for tuna fillets cooked at $68^{\circ} \mathrm{C}$ and stored at $5{ }^{\circ} \mathrm{C}$. Echarte et al. (2003) evaluated the nutritional composition of fish pate and reported values of $26.4 \%, 16.1 \%$ and $13.7 \%$, for salmon, anchovy and tuna fillets, respectively. Also, Aquerreta et al. (2002) found fat contents of 10.0\%, $28.9 \%$ and $26.2 \%$, respectively for tuna, salmon and anchovy. The differences obtained may be explained in terms of the different amounts of raw materials (fish and pulp) and other additives used in the formulation.

Concerning the determination of protein content, the values varied from $14.7 \%$ to $18.7 \%$ in experiments 6 and 17 , respectively. From Table 2, one can observe that higher protein contents ( $18.1 \%$ to $18.7 \%$ ) were obtained when lower temperatures were employed. Experiments 6,8 and 10 presented the lowest protein contents ( $14.7 \%$ to $15.4 \%$ ), probably caused by protein denaturation that occurred during protein extraction and emulsion time, favored by the high temperatures used in these experiments.

Figure 2 presents the Pareto chart depicting the effect of the investigated variables on protein content. From this figure, it can be observed that temperature exerted a negative effect on protein content. This result is in agreement with the literature, which reports a reduction in protein solubility in carps with increasing temperature (SAEKI; INOUE, 1997). This fact seems to be related to protein denaturation caused by physical agents (heat, irradiation, ultraviolet) and chemicals (guanidine chloride, urea, organic solvents, detergents and extreme $\mathrm{pH}$ conditions) (SAEKI; INOUE, 1997). The myofibrillars proteins of some fish species are thermal and chemically unstable compared to proteins obtained from other vertebrate animals (JONES, 1982). It should be mentioned that the presence of solubilized proteins during the sample preparation step, mainly after salt addition, is important to the formation of the interfacial proteic 
film on drop surface of lipid, so as to stabilize the emulsion (KINSELLA, 1976).

The ash content varied from $1.9 \%$ to $3.7 \%$ and these values are related to the curing salts, $\mathrm{NaCl}$ and other additives, ingredients of the nuggets formulation. On the other hand, lower ash contents $(\sim 1.5 \%)$ were observed in fresh fish, hence corroborating the influence of the ingredients on the ash content (SURH et al., 2005).

Table 2 shows that the experiments that presented lower protein contents led to higher ash contents in the fish nugget (experiments 6, 8, and 10). Conversely, experiments resulting in lower protein contents presented higher ash content (experiments 6, 8 and 10).

The $\mathrm{pH}$ values were also evaluated and varied from 6.1 to 6.9 for all experimental conditions. It was observed that higher temperature of water, fillets and pulp led to higher $\mathrm{pH}$ values. This result is in agreement with the work of Scherer et al. (2004), where the post mortem was showed to be characterized by the action of endogenous enzymes and microorganisms that change the nitrogen compounds present in fish meat, enhancing the $\mathrm{pH}$ at high temperatures. Possibly, this is the reason why the temperature specified for conservation of fish and its products is about $5^{\circ} \mathrm{C}\left( \pm 1^{\circ} \mathrm{C}\right)$.

$a_{\mathrm{w}}$ values from 0.98 to 1.0 were obtained in all experiments. Pate made from tilapia (O. niloticus) presented $a_{\mathrm{w}}$ values between 0.989 and 0.995 (MINOZZO, 2005). $a_{\mathrm{w}}$ values are related to the

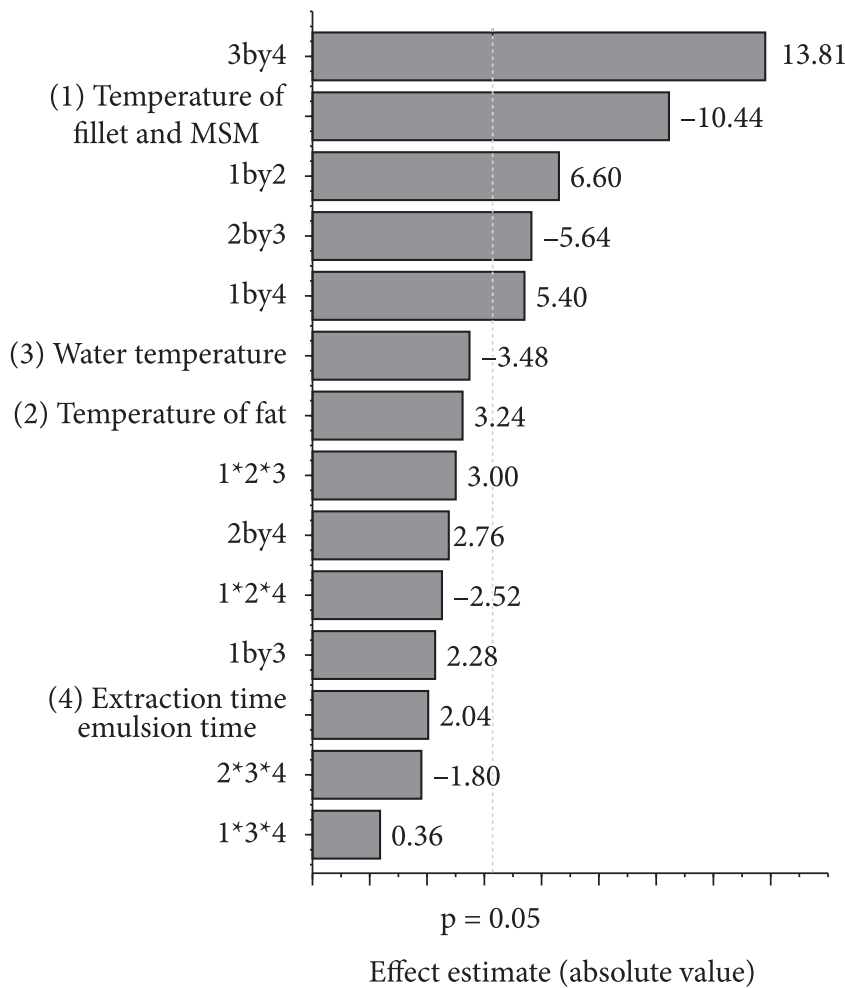

Figure 2. Pareto chart with the estimated effect (absolute value) of variables evaluated in the full $2^{4}$ experimental design in terms of protein content. interactions between fish compounds and water (CHEFTEL; CHEFTEL, 1992). Raw materials temperature had a negative effect on $a_{\mathrm{w}}$ values.

It can be noted that experiments 1 and 17, which presented the highest protein contents, also presented the highest moisture contents (Table 2). The high moisture values occurred as a consequence of high protein contents present in fish nuggets. This parameter is directly related to the water retention in the product. Statistical analysis showed that the interaction between protein extraction and time/emulsion time and fat temperature had a positive effect on moisture content. Some authors referenced that the fat content can favor the formation of small fat particles, which allow more efficient protein extraction and emulsion formation (SAEKI; INOUE, 1997; SATO et al., 2003).

Lightness $\left(L^{*}\right)$ values varied from 51.8 to 70.0 . Experiments 1 and 17 presented the highest lightness $\left(L^{*}\right)$ values $(69.7$ and 70.0 , respectively). From Table 2, one can learn that there is a straight relationship between lightness values and protein content. The values of red color $\left(\mathrm{a}^{\star}\right)$ varied from 8.9 and 5.0, for experiments 9 and 17, respectively.

\subsection{Microbiological analysis}

Table 3 presents the results obtained from the application of the experimental design related to the microbiological analysis. In all experiments, the total coliforms counting varied from 2.24 UFC. $g^{-1}$ to 3.62 UFC. ${ }^{-1}$. The lowest value was obtained for experiment 7 and the highest for run 8. Experiments number $10,3.30$ UFC.g ${ }^{-1}$ and number $2,3.41$ UFC.g ${ }^{-1}$, also presented

Table 3. Microbiological analyses in the fish nuggets product in terms of experimental conditions established in the experimental design.

\begin{tabular}{cccc}
\hline Run & $\begin{array}{c}\text { Total coliforms } \\
\left(\text { UFC. }^{*}\right)\end{array}$ & $\begin{array}{c}\text { Fecal coliforms } \\
\left(\text { UFC. }^{-1}\right)\end{array}$ & $\begin{array}{c}\text { Staphylococcus } \\
\text { coagulase }^{*}\left(\text { UFC. } g^{-1}\right)\end{array}$ \\
\hline 1 & $2.88 \pm 0.60^{\mathrm{a}, \mathrm{b}, \mathrm{c}}$ & $1.00 \pm 0.01^{\mathrm{a}}$ & $1.00 \pm 0.01^{\mathrm{a}}$ \\
2 & $3.41 \pm 0.20^{\mathrm{b}}$ & $1.59 \pm 0.13^{\mathrm{a}, \mathrm{c}}$ & $1.00 \pm 0.01^{\mathrm{a}}$ \\
3 & $2.77 \pm 0.59^{\mathrm{a}, \mathrm{b}, \mathrm{c}}$ & $1.00 \pm 0.1^{\mathrm{a}}$ & $1.00 \pm 0.01^{\mathrm{a}}$ \\
4 & $3.29 \pm 0.45^{\mathrm{a}, \mathrm{d}}$ & $1.30 \pm 0.35^{\mathrm{a}, \mathrm{c}}$ & $1.00 \pm 0.01^{\mathrm{a}}$ \\
5 & $2.36 \pm 0.21^{\mathrm{c}}$ & $1.00 \pm 0.01^{\mathrm{a}}$ & $1.00 \pm 0.01^{\mathrm{a}}$ \\
6 & $2.48 \pm 0.02^{\mathrm{c}, \mathrm{d}}$ & $1.00 \pm 0.01^{\mathrm{a}}$ & $1.45 \pm 0.10^{\mathrm{b}}$ \\
7 & $2.24 \pm 0.07^{\mathrm{c}}$ & $1.00 \pm 0.01^{\mathrm{a}}$ & $1.50 \pm 0.10^{\mathrm{b}}$ \\
8 & $3.62 \pm 0.41^{\mathrm{a}}$ & $2.39 \pm 0.32^{\mathrm{b}}$ & $1.35 \pm 0.01^{\mathrm{b}}$ \\
9 & $2.30 \pm 0.15^{\mathrm{c}}$ & $1.00 \pm 0.01^{\mathrm{a}}$ & $1.00 \pm 0.01^{\mathrm{a}}$ \\
10 & $3.30 \pm 0.51^{\mathrm{a}, \mathrm{b}, \mathrm{d}}$ & $2.49 \pm 0.34^{\mathrm{b}}$ & $1.39 \pm 0.01^{\mathrm{b}}$ \\
11 & $3.06 \pm 0.13^{\mathrm{a}, \mathrm{b}, \mathrm{c}}$ & $1.00 \pm 0.01^{\mathrm{a}}$ & $1.60 \pm 0.01^{\mathrm{b}}$ \\
12 & $2.89 \pm 0.09^{\mathrm{a}, \mathrm{b}, \mathrm{c}}$ & $1.00 \pm 0.01^{\mathrm{a}}$ & $1.00 \pm 0.01^{\mathrm{a}}$ \\
13 & $3.13 \pm 0.11^{\mathrm{a}, \mathrm{b}, \mathrm{c}}$ & $1.88 \pm 0.46^{\mathrm{b}, \mathrm{c}}$ & $1.39 \pm 0.01^{\mathrm{b}}$ \\
14 & $3.27 \pm 0.22^{\mathrm{a}}$ & $1.94 \pm 0.64^{\mathrm{b}, \mathrm{c}}$ & $1.00 \pm 0.01^{\mathrm{a}}$ \\
15 & $3.48 \pm 0.01^{\mathrm{a}}$ & $1.59 \pm 0.13^{\mathrm{a}, \mathrm{b}}$ & $1.30 \pm 0.01^{\mathrm{b}}$ \\
16 & $2.99 \pm 0.78^{\mathrm{a}, \mathrm{c}, \mathrm{d}}$ & $1.18 \pm 0.35^{\mathrm{a}}$ & $1.00 \pm 0.01^{\mathrm{a}}$ \\
17 & $3.51 \pm 0.02^{\mathrm{a}}$ & $2.54 \pm 0.28^{\mathrm{b}}$ & $1.00 \pm 0.01^{\mathrm{a}}$ \\
18 & $3.09 \pm 0.16^{\mathrm{a}, \mathrm{a}, \mathrm{d}}$ & $1.00 \pm 0.01^{\mathrm{a}}$ & $1.30 \pm 0.01^{\mathrm{b}}$ \\
19 & $3.23 \pm 0.32^{\mathrm{a}, \mathrm{d}}$ & $2.77 \pm 0.27^{\mathrm{b}}$ & $1.45 \pm 0.01^{\mathrm{b}}$ \\
\hline
\end{tabular}

"UFC. $\mathrm{g}^{-1}$ Unidade formadora de colônia $\mathrm{g}^{-1}$; mean of 3 replications, equal letters do not differ statistically at $5 \%$ (Tukey test). Total coliforms in the raw material: fillet 2.21 and pulp 2.10. 
high counting, probably due to the higher temperatures of raw materials (pulp and fillet) during product formulation. Other experiments that merit inspection, since high counting was obtained, are runs 13 and 14 . These results are due to high water temperature and extraction time and emulsion adopted in these experiments. It may be interesting to highlight the fact that these results are beyond the limit proposed by the French legislation - 3.00 UFC. $^{-1}$ (DANTAS; SILVA, 1982). The microbiological quality of catfish produced in the USA presented total counting from 1.30 UFC. $^{-1}$ to 3.20 UFC.g $^{-1}$ (FERNANDES et al., 1997).

The fecal coliforms counting varied from $1.00 \mathrm{UFC}^{-\mathrm{g}^{-1}}$ to 2.77 UFC. $\mathrm{g}^{-1}$ for all experiments performed. The differences observed may have resulted from manipulation, since the raw materials used in the processing step were obtained from fish caught in weirs, far away from any sewage (GONZÁLEZRODRIGUES et al., 2002). In a study performed by Peixoto, Sousa and Mota (2002), lower amounts of coliforms were found in fish sausages.

Table 3 reveals that the fecal coliforms counting in raw material (fillet and pulp) and in the final product (fish nugget) varied from $2.00 \mathrm{UFC}^{-1} \mathrm{~g}^{-1}$ to $2.77 \mathrm{UFC} . \mathrm{g}^{-1}$. The statistical analysis of experimental data showed that no variable presented a significant effect on thermo-tolerant coliforms $\left(45^{\circ} \mathrm{C}\right)$, with their presence directly related to the processing. One should notice that the values obtained here are in agreement with the legislation. The best results in terms of thermo-tolerant coliforms were achieved in experiments 1, 3, 5, 7 and 9, corresponding to lower temperatures of raw materials. It can also be observed that better results were reached for lower values of water temperature (experiments 1, 3 and 9).

The Staphylococcus coagulase positive counting varied from $1.00 \mathrm{UFC}^{\mathrm{g}} \mathrm{g}^{-1}$ to $1.60 \mathrm{UFC} . \mathrm{g}^{-1}$ in all performed experiments. Experiments 7, 1.50 UFC. $^{-1}$, and 11, 1.60 UFC. $^{-1}$, presented higher Staphylococcus coagulase positive counting, such counting figures were favored by water temperature and fat used for nuggets formulation.

The ideal value of $a_{\mathrm{w}}$ for $S$. aureus is 0.86 and the optimum $\mathrm{pH}$ for its growth and toxin production is between 6.0 and 7.0; and the enterotoxin production is detectable at 4.00 UFC. ${ }^{-1}$ (GONZÁLEZ-RODRIGUES et al., 2002). The $a$ and $\mathrm{pH}$ values in all experiments varied form 0.98 to 0.99 (Table 2) and 6.1 to 6.9 , respectively. These values show that the nuggets presented ideal conditions for Staphylococcus coagulase positive growth. However, the highest counting obtained (1.60 UFC. $\left.\mathrm{g}^{-1}\right)$ is lower than that necessary to enterotoxin production. Minozzo (2005) found Staphylococcus coagulase positive counting in tilapia fillets and pates lower than 2.00 UFC.g ${ }^{-1}$.

\section{Conclusions}

The production of fish nuggets was carried out in an industrial unit allowing the identification of manufacturing parameters that affect the final product. Conventionally, the method adopted for determining optimal conditions in industrial processes the variation of one parameter while keeping others at a constant level. This is a time and cost ineffective method that also presents the disadvantage of not including the interaction effects among its variables. Factorial design technique can overcome such drawbacks, but it has been seldom used to evaluate the effects of process parameters in the industrial environment. The physicochemical analyses performed in the final product showed that the higher the temperature of fish pulp and fillet, the lower the protein level in the final product. The microbiological analyses also led to Staphylococcus coagulase positive, total coliforms and thermotolerant coliforms counting in agreement with the legislation.

\section{References}

AMERICAN PUBLIC HEALTH ASSOCIATION - APHA. Compendium of Methods for Microbiological Examination of Food. 3th ed. Washington: APHA, 1992.

AQUERRETA, Y. et al. Composition of pâtés elaborated with mackerel flesh (Scomber scombrus) and tuna liver (Thunnus thynnus): comparison with commercial fish pates. Food Chemistry, v. 77, p. 147-153, 2002. http://dx.doi.org/10.1016/S0308-8146(01)00310-7

BRASIL. Ministério da Saúde. Agência Nacional de Vigilância Sanitária. Métodos Físico-químicos para Análise de Alimentos. 4. ed. Brasília: Ministério da Saúde, 2005.

CASTRO, A. I. et al. Sensory evaluation of a milk formulation supplemented with $\mathrm{n} 3$ polyunsaturated fatty acids and soluble fibers. Food Chemistry, v. 85, p. 503-512, 2004. http://dx.doi. org/10.1016/S0308-8146(02)00456-9

CHEFTEL, H.; CHEFTEL, J. C. Introducion a la bioquimica y tecnología de los alimentos. 2. ed. Zaragoza, Espanha: Acribia, 1992. v. 1. 333 p.

DANTAS, R. A.; SILVA, M. C. C. Microbiological analysis of meals prepared in Canteens. Lisboa: Codex, 1982.

ECHARTE, M. et al. Evaluation of the nutritional aspects and cholesterol oxidation products of pork liver and fish pâtés. Food Chemistry, v. 86, p. 47-53, 2003. http://dx.doi.org/10.1016/j. foodchem.2003.08.027

FERNANDES, C. F. et al. Influence of processing schemes on indicative bacteria and quality of fresh aquaculture catfish fillets. Journal of Food Protection, v. 60, n. 1, p. 54-58, 1997.

FLORES, E. R. et al. Tecnologia de processamento de filetes de ahumados de atún. Ciência e Tecnologia de Alimentos, v. 12, n. 1, p. 23-26, 2002.

FRANCO, B. D. G. M.; LANDGRAF, M. Microbiologia dos Alimentos. São Paulo: Atheneu, 1996. 182 p.

GERMANO, P. M. L.; OLIVEIRA, J. C. F.; GERMANO, M. I. S. O pescado como causa de toxinfeções bacterianas. Higiene Alimentar, v. 7, n. 28, p. 40-45, 1993.

GONZÁLEZ-RODRIGUES, M. N. et al. Numbers and types of microorganisms in vacuum-packed cold-smoked freshwater fish at the retail level. International Journal of Food Microbiology, v. 77, p. 161-168, 2002. http://dx.doi.org/10.1016/S0168-1605(02)00048-X

HALL, G. M. Fish Processing Technology. New York: VCH Publishers, 1992.

INSTITUTO ADOLFO LUTZ - IAL. Manual para Análise de água do Instituto Adolfo Lutz. São Paulo: IAL, 2007. Disponível em: $<$ http://www.ial.sp.gov.br>.

JONES, K. W. Effects of chopping temperature on the microstructure of meat proteins. Journal of Food Science, v. 47, n. 12, p. 19301935, 1982. http://dx.doi.org/10.1111/j.1365-2621.1982.tb12916.x 
JORY, D. E.; ALCESTE, C.; CABRERA, T. R. Mercado y comercialización de tilapia en los Estados Unidos de Norteamérica. Panorama Acuícola, v. 5, n. 5, p. 50-53, 2000.

KINSELLA, J. E. Functional properties of proteins in foods: a survey. CRC Food Science Nutricion, v. 7, n. 3, p. 219-280, 1976. http:// dx.doi.org/10.1080/10408397609527208

MINOZZO, M. G. Elaboração de patê cremoso a partir de filé de Tilápia do Nilo (Oreochromis nicolicus) e sua caracterização físico-química, microbiológica e sensorial. 2005. 127 f. Tese (Doutorado em Tecnologia de Alimentos)-Universidade Federal de Paraná, Curitiba, 2005.

MONTGOMERY, D. C. Montgomery: Design and Analysis of Experiments. New York: John Wiley and Sons, 1991.

PEIXOTO, M. R. S.; SOUSA, C. L.; MOTA, E. S. Utilização de pescada (Macrodom ancylodon) de baixo valor comercial, para obtenção de surimi empregado na elaboração de salsicha com sabor camarão. Higiene Alimentar, v. 16, n. 99, p. 95-101, 2002.

REDMAYNE, P. Como el camarón y el salmon de cultivo la tilapia se está conviertiendo rápidamente em un proveedor de filetes frescos y congelados de alta calidad. Virtualmente todos los filetes de tilapia vendidos em los Estados Unidos son importados. Panorama Aquícola, v. 5, n. 3, p. 8-9, 2002.
SAEKI, H.; INOUE, K. Improved solubility of carp myofibrillar proteins in low ionic strength medium by glycosylation. Journal of Agricultural and Food Chemistry, v. 45, p. 3419-3422, 1997. http://dx.doi.org/10.1021/jf970302t

SATO, R. et al. Stability and emulsion-forming ability of water-soluble fish myofibrillar protein prepared by conjugation with alginate oligosaccharide. Journal of Agricultural and Food Chemistry, v. 51, p. 4376-4381, 2003. PMid:12848513. http://dx.doi.org/10.1021/ jf021023v

SCHERER, R. et al. Efeito do gelo clorado sobre parâmetros químicos e microbiológicos da carne de carpa capim (ctenopharyngodon idella). Ciência e Tecnologia de Alimentos, v. 24, n. 4, p. 680-684, 2004. http://dx.doi.org/10.1590/S0101-20612004000400034

$\mathrm{SU}, \mathrm{K}$. et al. O mega-3 fatty acids in major depressive disorder. A preliminary double-blind, placebo-controlled trial. European Neuropsychiatry, v. 13, p. 267-271, 2003. http://dx.doi.org/10.1016/ S0924-977X(03)00032-4

SURH, J. et al. Influence of Environmental Stresses on Stability of O/W Emulsions Containing Cationic Droplets Stabilized by SDS-Fish Gelatin Membranes. Journal of Agricultural and Food Chemistry, v. 53, n. 10, p. 4236-4244, 2005. PMid:15884866. http://dx.doi. org/10.1021/jf047944i 